\title{
Libraries of the Ages:
}

\section{THE DIGLIBS}

\author{
Madhu Bhargava \\ Dean of Libraries \\ G.D.Goenka World School \\ India
}

Digital libraries are a way to cost effective Reading resources for school librarians. They can build Reading Communities through digital libraries. A case study of G.D.Goenka Schools in India will be presented in the paper. The current economic trends in the Information and Publishing industry will be examined and how school librarians are affected. Digital Libraries as reading resources are a new paradigm that may help to meet the economic parameters of the institutions. The paper will compare digital Reading resources with traditional reading resources and It will establish that $21^{\text {st }}$ century learner is truly digital native and is very confident and comfortable with technology and online reading. It will also be emphasized that it is the format, which is changing, and not the content or its importance. The main goal of this paper is to show how school librarians can adopt strategies to use free digital reading Resources to build reading communities of young and young adult students by providing case studies and a Tool-Kit used by the school.

Digital reading resources, reading strategies, reading programs

\section{Introduction}

"Current economic trends in the information industry are rapidly bringing traditional libraries to the point of ruin." Brian Hawkins wrote in his article, "Creating the library of the future: Incrementalism won't get us there!" in 1994 at Brown University. His argument at that time is proving to be true that "urgent financial crises of our libraries make it clear that the traditional library will not scale into the next decade."

Among the trends Hawkins cited at that time were the rapidly increasing amounts of available and declining drastically purchasing powers of the libraries. He called for the new and revolutionary paradigm to be developed that would meet the economic parameters of the institutions and would still support the traditional values of libraries and scholarship. For all of us present here to this Conference, DIGLIBS are that paradigm. In Hawkins words, DIGLIBS provide "universal access by students and faculty to information in all possible media via a single multifunctional workstation." According to him digital library is specifically both a solution to the economic problem facing libraries and a vehicle for a new functionality that promises to transform scholarship and bring the cultural, social and economic benefits of information to the many." 


\subsection{Building Reading Communities in School Libraries through Digital libraries.}

The world of our students in schools has become more and more visuals based and with new technology in hands, willingness to hold print is substantially falling. This is global impact. We are witnessing technology boom all over. For underprivileged low technology and for privileged high technology but most of us have technology or the governments are looking into it.

"The school library is an educational and cultural environment where individuals are exposed to ideas through the use of print and non-print resources in many media formats. The school library fosters the development of life-long learning abilities and a love of reading in its students." (Markuson, 1999)

\section{Easier said than done! How do we do it?}

The children in front of us have a different childhood than what we have had. It is a challenging task to plan reading program for the student community. http://www.icdlbooks.com or http://www.magicalkingdom.co.uk/story.html, http://magickeys.com were the guideline for my future planning and designing of reading programs for the student community at G.D.Goenka Schools. The exciting journey began with designing of Information Literacy projects which followed 'big 6 model'. Eisenberg and Berkowitz (1987) The students were required to read online from digital or E-libraries and explore information through other links. For example the online book on the web site http://www.magickeys.com students were to read a Chinese tale originally written by Po Chung Ling, retold by Teresa $\mathrm{Ng}$ and write a T.V. commercial for the book reflecting Conservation of Wild Life. Another group of students read Daniel's Ride on http://www.icdlbooks.org and described an experience they've had that was like the experience of the character Daniel and they had to think of their dream and write that how much time they think they would take to make it real? In a short while, we realized that it was happening and the journeys became more and more enjoyable with more and more sources and ideas.

\subsection{How it started in G.D.Goenka World School?}

Reading is fundamental to be successful in any subject. It is an arduous task for the librarians to help develop reading skills in a strategic manner particularly when students come from different backgrounds and have varied reading levels. Technology offers potential support to the librarians who can use digitized reading resources to improve reading skills of the Digital Natives who are actively engaged with Technology.

We have a large percentage of students who speak second languages like Korean, Japanese and Spanish etc, in the first category, followed by diverse reading abilities, making Librarians task very challenging while designing Reading programs involving whole school 
community. Students in the second category are equipped with new technology with least or no interest in reading. One can see them always engaged with games, music, movies, photographs, communication and everything else resulting into lower academic grades.

I came across the International children's digitized library collection in 2004 and introduced reading to the students in library lesson on library computers. The student response was astonishingly positive.

We explored more of E-books collections and created a mock tail of www.icdlbooks.org, www.pagebypage.com, www.magickeys.com with an assignment which they would work and send me through e-mail. Student response graph went up dramatically and with evidence in the form of e-mail.

We started building up strategies and collection to promote and build reading communities through digital libraries.

\section{Current Economic trends in the Information and Publishing industry}

Rising prices of print resources, falling library funds and exponential growth in the graph of resources and information are posing the two most fearsome challenges to libraries worldwide. What are these challenges? Of course the challenges are like beasts sleeping next to us. Whatever part of the world we are in, we are aware of every grunt and twitch of the beasts. And the beasts are Economic Survival and Preservation of resources.

\subsection{How School Libraries are affected by the Economic trends?}

What I am going to write now has been written by many and all in very many words and yet I must write the same in yet different words that future development of an individual is linked to reading habits of a person. It is the urgent responsibility of school libraries to provide students with reading opportunities which suit them the best.

Schools are caught in dizzying tempo of globalization and technological change and libraries are trying to survive from economic pressures, declining finances. It is at this backdrop, it is most appropriate to present Indian scenario about book publishing industry.

Mainstream publishing today caters to two kinds of markets-quality books for the more discriminating English-speaking urban elite and mediocre to poor quality books for the masses made up of India's vast and growing middle class. This marketing frenzy and hype leaves the huge majority of Indian children out in the cold. For the publishers, it is a challenge to produce financially viable books for children. It is all about gap between the two types which you can gauge by analyzing the following table of purchase cost of imported books for children up to age level 10 years and locally produced books. 


\begin{tabular}{|c|c|c|c|}
\hline Publisher & Title/ISBN & prices & $\begin{array}{l}\text { Indian } \\
\text { currency } \\
\text { converted }\end{array}$ \\
\hline Usborne & $\begin{array}{l}\text { 978-0-7460- } \\
5226-6\end{array}$ & $\begin{array}{l}\text { UKP } 4.99 \\
+ \text { freight }\end{array}$ & \\
\hline $\begin{array}{l}\text { Scholastic } \\
\text { Inc }\end{array}$ & $\begin{array}{l}\text { 0-439- } \\
33619-8\end{array}$ & $\begin{array}{r}\text { US \$ } \\
3.99+\text { freight }\end{array}$ & \\
\hline $\begin{array}{l}\text { Story } \\
\text { sack, UK }\end{array}$ & $\begin{array}{r}\text { Code } \\
\text { RH9965 }\end{array}$ & $\begin{array}{r}\text { UKP } \\
5.99+\text { freight }\end{array}$ & \\
\hline $\begin{array}{l}\text { Raintree, } \\
\text { UK }\end{array}$ & $\begin{array}{c}1-844- \\
43509-8\end{array}$ & $\begin{array}{r}\text { UKP } \\
6.99+\text { freight }\end{array}$ & \\
\hline $\begin{array}{l}\text { Oxford, } \\
\text { UK }\end{array}$ & $\begin{array}{l}9780192727 \\
046\end{array}$ & $\begin{array}{r}\text { UKP } \\
5.99+\text { freight }\end{array}$ & \\
\hline $\begin{array}{l}\text { Scholastic, } \\
\text { India }\end{array}$ & $\begin{array}{l}0-439- \\
01120-5\end{array}$ & $\begin{array}{r}\text { INR } \\
100.00\end{array}$ & US\$ 2.36 \\
\hline $\begin{array}{l}\text { Penguin, } \\
\text { India }\end{array}$ & $\begin{array}{r}\text { 0-14- } \\
029448-1\end{array}$ & $\begin{array}{r}\text { INR } \\
250.00\end{array}$ & US\$ 5.90 \\
\hline $\begin{array}{l}\text { Picador, } \\
\text { India }\end{array}$ & $\begin{array}{l}0-330- \\
49131-8\end{array}$ & $\begin{array}{r}\text { INR } \\
225.00\end{array}$ & US\$ 5.31 \\
\hline $\begin{array}{c}\text { Children } \\
\text { Book Trust, India }\end{array}$ & $\begin{array}{l}\text { 81-7011- } \\
768-2\end{array}$ & INR 22.00 & US\$ 0.51 \\
\hline
\end{tabular}

School Libraries in India have little or no budget for resources. Librarians have to justify the school management for ever declining financial approvals to purchase resources. The approvals are need based and librarians are on the lookout for alternatives.

Above analysis clearly indicates that it is a daunting task for school librarians to create a balance in the quality and cost while preparing a financial proposal for both the varieties of books. The big question is exposure. What exposure is being given to the students? Are they exposed to the literature that includes realities of the world and that of the world outside through stories and pictures?

\subsection{Digital Libraries emerging as New Paradigm}

"Digital Libraries are emerging as the most cost-effective way to preserve and distribute an ever increasing base of information resources." (Record, 1996).

\section{What is a digital library?}

"Digital libraries combine the historical wealth of the traditional library with the advanced technology-digital storage, processing, and communications - of information management systems. Digital libraries enable users to manage tremendous amounts of information as well as many types of media; to conduct searches that would be impractical manually; and to perform rapid information distribution and retrieval across great distances. 
The result is that library information is more accessible, more usable, and simply more valuable to faculty, students, and administrators - even, perhaps, to scholars the world over." (Record, 1996).

"Digital Library is a confusing term to the librarians. It seems that the word "library" has been appropriated by many different groups to describe their areas of research or signify a simple collection of digital objects. (Cleveland, 1998)

But the focus of this paper is looking into the reading strategies which may be adopted by the school librarians to enhance or introduce the use of Digital Libraries to school students. The resources mentioned in the Tool-Kit are either Digital Libraries or e-Books as per the working definition given below:

"Digital libraries are organizations that provide the resources, including the specialized staff, to select, structure, offer intellectual access to, interpret, distribute, preserve the integrity of, and ensure the persistence over time of collections of digital works so that they are readily and economically available for use by a defined community or set of communities." (DLF, 1998)

The E-book paradigm is also evolving since the time in 1987 when the first hypertext novel by Michael Joyce, 'Afternoon Story' and fast forwarding to $21^{\text {st }}$ century with the Stephen King's online novella, 'Riding the bullet', in 2000. A plethora of Digital Libraries and Eresources is available for free and for purchase, for downloading and for printing off the web.

Truly the dream of Brian Hawkins has become a reality!

\section{Digital Reading Resources vs. Traditional Reading Resources}

If you have technology tool, rapid and easy access to information and books, archives and images is just few clicks away.

- Traditional libraries have scarce space; potential of digital libraries to store much more information is enormous.

- The Internet connection takes you to Digital Libraries instantly; physical effort is the pre-requisite to access the traditional library.

- $24 \times 7$ availability of Digital Library resources; limited access in case of traditional libraries.

- Digital libraries may be accessed by multiple users globally; traditional libraries have limitations of space and time.

- Digital Libraries provide access to much richer and diverse content in a more structural manner whereas traditional reading resources collections offer time consuming searches.

- Digital library collections offer user friendly search and navigation facility then the conventional search via catalog or OPAC in traditional searches. 
- Digitization is a solution to preservation and conservation of resources whereas traditional libraries struggle with the same issues.

- Networking with other digital library resources is possible easily, making a seamless resource sharing possible which is just not possible in other case.

- Cost of maintaining digital library operations are low cost than traditional library but it is also true that digital libraries do incur large costs for digitization equipment, maintaining online access and migrating to new technology when it is obsolete. But it is also true that there are free digitized reading resources in abundance for School librarians to motivate their students to use and benefit particularly in developing and underdeveloped countries and don't worry about funds.

\subsection{The Digital Natives}

"What should we call these "new"students of today? Some refer to them as the N-(for Net)-gen-or D-[for digital]-gen. But the most useful designation I have found for them is Digital Natives. Our students today are all "native speakers" of the digital language of computers, video games and the Internet." (Prensky, 2001)

"The digital age has brought radical changes to our students. Our D-Generation students have an unprecedented access and appetite for Technology. Our children are ever ready voracious consumers of digital games, videos, music and web. They are being addressed as 'digital natives' who have enthusiastically embraced technology as their friend and are very comfortable at study, work, play, communication and entertainment (Culligan, 2003).

But it is ironical that our schools and libraries are frozen in the $20^{\text {th }}$ Century in most countries including many developed. There is dark little joke in the education world: "Rip Van Winkle awakes in the $21^{\text {st }}$ Century after a hundred year snooze and is, of course utterly bewildered by what he sees. Men and Women dash about, talking to small metal devices pinned to their years. Young people sit at home on sofas, moving miniature athletes around on electronic screens. Older folk defy death and disability with metronomes in their chests and with hips made of metal and plastic. Airports, hospitals, shopping malls - every place Rip goes just baffles him. But when he finally walks into a school room, the old man knows exactly where he is. "This is a school", he declares, "We used to have these back in 1906. Only now the black boards are green."(Wallis and Steptoe, 2006)

The digital natives are amazing people for whom the Internet and new technology is not produce of transformative era, but like water and electricity and many other available basics of facilities, have always been there. Fast track information, networking, multi-tasking are the common features of D generation. The digital native can do his or her research work while listening to the favorite music, chatting with four to five people and taking calls in between on the cellular phone, at the same moment expressing boredom! 
The web of digital environment is already set even in developing countries. It is challenging for digital migrants, like me or many of us especially in developing countries, to design an educational curriculum which sharpens the digital literacy skills of digital natives.

All these facts at the back of mind with new technology in hand which is encouraging, librarians in developing countries have all the opportunity to design reading programs using e-books, digital library collections for the new age students.

\subsection{The content is the king}

It is risky to predict future but it is almost evident today that future school library may or may not look different but will play the role differently. New research, new information and explorations are leading us into a universe of exponentially expanding knowledge. Globally speaking e-resources are replacing print though the demise of the book is not evident for a long time. And it may not happen the way it happens in the mind of the digital migrant librarian!

The concept of the 'book' will remain, but as we see digital formats are taking over print. The look and feel 'bookish' will be replaced with the high tech optical devices. Where is the worry? If we look at the development of any current devices, be it vehicles, phones or any communication devices and compare the ancient formats to that of today... what we understand is that it is not the format, which is critical, but the content. The decision of format should be consistent with the quality and utility of information in current times. No wonder in an information rich and technology driven society e-books and digital libraries are fast replacing printed texts. It is high time that we give a push to the school libraries out of $20^{\text {th }}$ century so that Rip Van Winkle continues with the surprises!

\subsection{Strategies to build Reading communities in Schools}

Availability of DIGLIB resources is not enough. The pedestrian element is building reading community of students in school. How do we do that? Librarians may find useful the following repertoire of Reading Strategies to develop reading communities in school.

- $\quad$ Demonstrate your familiarity and skill to navigate the contents of digital resource you wish your students and faculty members to use. Give presentation of the same at appropriate times to develop use as these resources are invaluable for use in teaching language, literature, history, science and much more. Our recent presentation on the E-books on www.magickeys.com in the assembly of grades II-V, yielded results in the form of enquiries of 'more such sites', faculty response in the form of developing language assignments based on the highlighted words in the stories of this resource.

- Collaboration is the key strategy to involve whole student community. Address the teaching community who lack time to explore resources for their lessons. There is immense wealth of digitized collections of primary resources in science, History, Literature, Language for research and curriculum oriented areas. The school librarians can save on funds and time and provide universal accessibility to the teaching 
community by developing a classified collection of digitized and e-Resources at hand. Collaborate early to provide optimum benefit to the faculty and send the resources on their desk top and they will find their way. In our institution http://cvc.cervantes.es and http://www.icdlbooks.org are most loved collections for language teachers.

- $\quad$ Develop lesson plans and assignments which would necessitate the use of digital resources. One such example is designing of fun filled assignment 'Reading Mission' for the holidays which challenge students to visit the web sites provided and submit the assignment on line or off line. Case study sample one is an assignment which was web posted on www.gdgoenka.com in May 2007.

- $\quad$ One of the prime missions of school libraries is to adopt such strategies that the students become fluent readers. Students should be able to imply thinking, understanding, questioning, visualizing and inferring while reading. It is a daunting task. Our students are very comfortable with the technology and that's what we are eying. Make our students read through technology and give them ample exercise to practice comprehending. It becomes essential for the librarians to select and plan the lessons based on digital reading resources.

- Compile a ready Tool-Kit of free digital resources particularly in developing countries where library finance is mostly the least if not the last priority.

- $\quad$ Create a promotion program following modern marketing techniques for reading and resources and when responded by the student or teacher community, provide recognition and reward points. We used 'AASL@your library' tool-kit for this purpose with $\mathrm{A}+$ result.

- $\quad$ Train The Trainers (The teacher community) to use digital sources in the class rooms by conducting workshops for them.

- Net work with other librarians and share the wealth of digital sources which in turn is bound to grow.

- $\quad$ Provide reading guidance and support to the student community even if they ask from home or elsewhere.

\section{The Reading Mission: Case study one}

\section{Strategies used:}

- $\quad$ Create a promotion program following modern marketing techniques for digital reading resources.

- $\quad$ Compile a ready Tool-kit of free digital resources.

\section{Overview}


The following assignment was aimed at developing innovative and fun filled thinking based reading. It was focused to communicate directly with the students to prompt them to access Digital Libraries mentioned in the assignment from home or anywhere during vacations and communicate with other students and librarian via e-mail regarding their progress in the mission. The program was designed for all K-12 age groups but was particularly aimed at Middle School age group when students are required to develop reflective and response based reading habit. Another purpose of this assignment was to engage students in reading even if they are away from home and are connected to the Internet which according to our experience, they always are. This program was also intended to involve students in discussions with their peer group regarding reading experience from Digital resources. The program was incentives based to create intentional competition for reading more and more.

(The assignment was designed with colors and animated objects)

\section{$\underline{\text { A note for Parents/students }}$}

This summer vacation students @G.D.Goenka World school will accomplish ONE TOP SECRET MISSION!

Aim: This initiative is aimed towards encouraging students to read and discuss books in a lively and engaging manner and help discover the pleasure and excitement of reading.

Reading Mission is planned so as to promote a sense of achievement among young readers. It will empower children by encouraging them to make their own book selection.

"Another objective of this mission is to help our children in becoming effective members of the global community, who exhibit tolerance and respect for diverse cultures, languages and ideas-by making the best in children's literature available online FREE OF CHARGE." ( From ICDL Mission statement)

Students from Grade one to Grade eight shall be the 'READING MISSION AGENTS' and will use digital archives of a Project of University of Maryland in cooperation with Internet Archives. There are more of interesting, interactive and child friendly sites to read books of their choice of language, country and type. Then they will work on bright SPY IDEAS to communicate with other 'Reading Mission Agents'

The Mission is to read Ten Books in Sixty Days, no matter where you are!

The Mission is high and students who will achieve this will be given GREEN BADGES specially designed for this Mission. Who get closer to the Mission will get YELLOW BADGES

and who will be slow, will get RED BADGES, depending on the number of books read and 'SPY IDEAS' accomplished, submitted after the holidays. By next summer our mission @ GDGWS is to have all students with GREEN BADGES!

Acknowledgement: 
The Dean of Libraries, G.D.Goenka World School, has compiled this Program and some ideas have been adopted from British Council library, New Delhi and from the web site http://www.readingmission.org.uk

\section{Hi Kids!}

Are You Ready For The Challenge?

THE READING MISSION

This Program will be for Two Months (summer vacations)

You can click here or open on your own the following web sites:

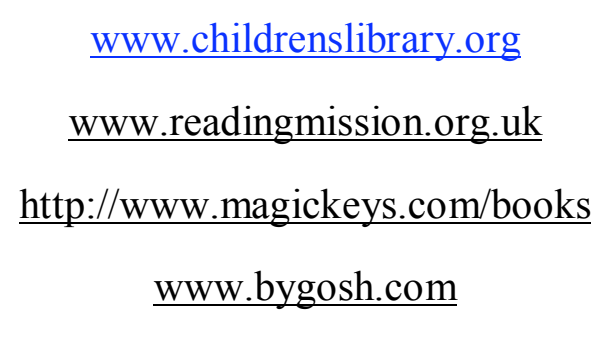

These sites can be very good friendly libraries!

And a treasure of interesting books.

I promise you will enjoy these!

You can register with some of these, which is very very easy!

Any problems, mail to

Madhu_bhargava@msn.com

YOUR MISSION IS

To READ Ten BOOKS OF YOUR AGE LEVEL

- Of your choice of Country

- Of your choice of Language

- Of your choice of type

- $\quad$ Work on the 'SPY IDEAS' given right here. 
- You can take out a print out and to make the mission fun filling and exciting.

- You can accomplish as many ideas as you can and your success depends on that!

- $\quad$ You have the freedom to use pens, stickers, colors, pencils and any other form of art, craft, and computer skill to reveal the content on the activity sheet.

- These Holidays hundreds of Goenkans will READ from this site but no one will know who is reading what!

- If you want you can send clues to your friends, and more the clues sent (I would ask for proof), higher the credit! So this summer get connected with your friends!

Create a Reading Mission Folder

And keep all the work sheets in that

After the holidays

Submit the accomplished activity sheets

To your Form Tutor

Latest

By the end of $1^{\text {st }}$ week of August 2007.

These ideas are according to age groups.

Print out sheets as per your age group.

Age 5 to 12 years

Send Top Tips to other Reading Agents

And see them on the school web site on a special link!

Also send a copy to

Madhu_bhargava@msn.com

Maximum number of sent tips may get you prize!

MAKE YOUR MISSION DECISION

(Animated Object) 
Where is your Reading Mission going to take you?

Try this simple quiz

And then create your Reading Plan Log

On day 1 of your holidays

And check your targets at every 7 days

Look for excitement waiting for you!

Color the answer in GREEN

Which of these would you like to accompany you on your mission?
a. Your Dog
b. Your Cat
c. Your Friend
d. Your Brother or sister

Now make your choice of gadget.
a. Exploding I pod.
b. Doughnut transmitter
c. Satellite link sugar bowl
d. Digital camera toothbrush

Where's your favorite spy spot?
a. The skateboard park.
b. The top of bus.
c. The school playground.

d. The tree tower

You're on an observation mission. What is the first thing you should pack?
a. Binoculars
b. Lunch
c. Mobile phone
d. MP3 Player

Hay spies! If your answers match with my answer you get a "gift!" 


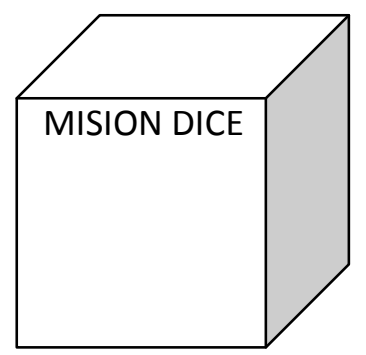

Can't decide on your next book for the Reading Mission?

Want to try a dice dare?

Let the dice roll!

Stick this shape onto

Stiff card, cut it out, and fold

Flaps and glue together.

When the dice is ready

Think of a number and throw

Whatever comes?

You may try reading that!

Isn't it amazingly easy!

\begin{tabular}{|c|c|c|}
\hline & $\begin{array}{c}1 \\
\text { Author you've } \\
\text { never read }\end{array}$ & \\
\hline \multirow[t]{2}{*}{\begin{tabular}{l}
\multicolumn{1}{c}{$\mathbf{2}$} \\
A Book by \\
your favorite \\
A ithnr
\end{tabular}} & $\begin{array}{c}3 \\
\text { An adventure } \\
\text { story }\end{array}$ & $\begin{array}{c}4 \\
\text { Choose an } \\
\text { Animal Book }\end{array}$ \\
\hline & $\begin{array}{l}\mathbf{5} \\
\text { Choose a } \\
\text { funny story }\end{array}$ & \\
\hline
\end{tabular}


Choose a scary Book

Create SPY bookmarks to record the way you felt about a book.

"The Best Book Mark"

Creator

Will get a 'Gift!'

Fold and submit and wait for results!

( A Template for making the Books Mark was given here)

\section{SPOT THE BONES AND WIN A PRIZE!}

There are more than 10 bones in this picture.

Find and color 


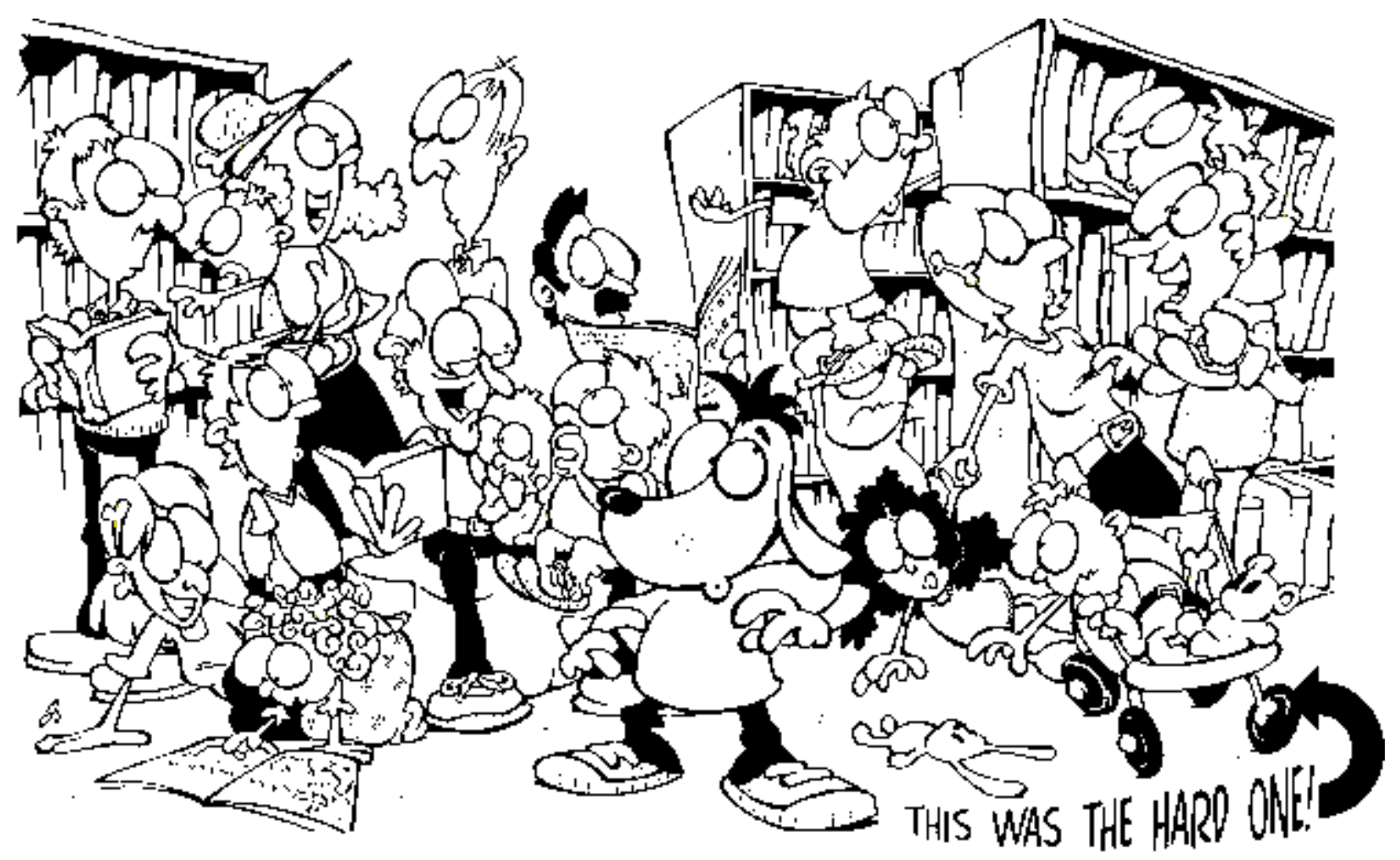

IT IS NOT SO EASY!

A GES 10-13

Hello the Super Spies! This message comes from your favorite sleuth hound, always remember, a good detective is never without a magnifying glass, a note book, pen and a cunning disguise, so sneak off all the good web sites I have given you to discover a great book today.

Hey!

If you can crack this code, send it to my mail box Madhu bhargava@msn.com

I promise you a beautiful "gift" exclusively for you!

Ruthua nanoc layod detaerc kcolrehs Semloh 'Eht Evitceted'

Do it and get a prize!

Mail your answer just now to

Madhu bhargava@msn.com

ARE YOU SUPER SPY? Do this quiz and find out!

1. Which of these activities can you do? Tick the boxes 


\begin{tabular}{|c|r|r|}
\hline $\begin{array}{c}\text { Drive a } \\
\text { sports car }\end{array}$ & Fly a plane & \\
\hline $\begin{array}{c}\text { Ride a } \\
\text { motorbike }\end{array}$ & Ride a horse & \\
\hline $\begin{array}{c}\text { Drive a } \\
\text { speedboat }\end{array}$ & Pilot a & \\
\hline
\end{tabular}

2. How good are you at these activities? Tick the box

\begin{tabular}{|c|c|c|c|}
\hline & good & okay & Terrible \\
\hline $\begin{array}{c}\text { Swimming } \\
\text { underwater }\end{array}$ & & & \\
\hline Snorkeling & & & \\
\hline judo Doing karate or & & & \\
\hline Fharks & & & \\
\hline $\begin{array}{c}\text { Skighting off } \\
\text { mountain }\end{array}$ & & & \\
\hline Parachuting & & & \\
\hline from a plane & & & \\
\hline
\end{tabular}

3.

safe?
How long would it take you to crack open a

10 minutes

60 seconds

3 seconds 
4.
a)
b)
c)
More than 5
2-4
only one

5.

How would you feel?
a)
b)
c)
Very calm
Scared
In total panic

6. puzzles?
a)
b)
c) Okay if you have enough time
Brilliant- a super brain
You never crack the code!

How many languages do you speak?

Imagine you had 5 seconds to defuse a bomb!

How good are you at cracking codes and

\section{Key to Super Spy! \\ 25-32- Super Spy \\ 15-25-Assistant Spy \\ 0-15---Go To Spy School}




\author{
DESIGN AN INNOVATIVE GADGET, WHICH A SPY CAN USE! \\ IF IT WILL WORK, YOU GET SCIENTIST AWARD!
}

AGE GROUP 10-13

READING LOG

\begin{tabular}{|c|c|c|r|r|}
\hline TITLE & AUTH & START & PLACE & FINISH \\
& OR & DATE & $\begin{array}{c}\text { WHEREYOU } \\
\text { ARE }\end{array}$ & ING DATE \\
\hline & & & & \\
\hline & & & & \\
\hline
\end{tabular}

\title{
IDEAS FOR YOU TO WORK OUT!
}

1. Plan a dinner party for the characters you liked the most. Write instructions to the catering staff, including the menu, table setting and guest list of celebrities.

2. Make a TV script for one scene of the book you have read.

3. Write a different ending of the book you have read.

4. Pretend you are from another century and you found this book in a time capsule. Make a list of questions would you have about the characters, setting and events in the book.

Brainstorm other titles for the book and design illustrated Book Marks that relate to each of the titles. Submit the Book Marks in the Reading Mission Folder. The Best entry will get a price and appreciation Certificate and 1 extra grade for Holidays assignment! Design an innovative gadget for a present day spy. If you show it working and give the report, you stand a chance for scientist award.

Acknowledgement: Some of the spy ideas have been adopted and modified from the original idea from the web site: www.readingmission.org.uk 


\section{Strengths and positive results of the program:}

- $\quad 40 \%$ students browsed through the instructional plan and sent quarries or communicated through e-mail.

quiz.

- $\quad 70 \%$ students tried the work sheets like 'Cracking the Code' and Super spy

- $\quad 50 \%$ students (age group 10-13) opened the web sites and tried to read and filled up the Reading Log.

- $\quad 25 \%$ students submitted Reading Mission folders with average work.

- $10 \%$ students submitted excellent Reading Mission folders.

\section{Weaknesses of the program:}

- The program did not set any parameters for those who did not do anything.

- It took long to reply mails which may have resulted in dropped levels of interest.

- We could not check the networking of the students. We had to rely on data given by students.

- There was no Collaboration with Teacher community for the reason the program was taken as Library assignment.

Strategies which could get better outcomes:

- $\quad$ Train the Trainer (TTT) could make these results many folds if this was done in collaboration with teaching community.

- $\quad$ Networking with other Librarians and asking for better support from the Technology department of the institution.

On the whole it was an encouraging outcome and it was away from assignments full of drudgery and it was much appreciated by the students. 


\subsection{Project Book Club: Read For Fun@ Cyber Space: A case Study}

Strategies used:

- Provide Reading guidance and Support.

- Collaborate with the Teacher community

\section{Over view:}

To become independent readers and comprehend text, it is important for our middle grade students to follow guided reading instruction, which majority of our student's lack. Dialogue with self, Visualization and connection with self and text help students become successful readers.

We created a set of questions based on QRA paradigm (Buehl, 2000) and implied on students. A presentation on, Right There, Author and Me, On My Own, Think and Search was given collectively and Sample story Daniel's Ride in digitized form at http://www.icdlbooks.org was presented.

Student Objectives:

- To Work in groups (not more than 6) and choose a team leader.

- Browse the web sites http://www.publicliterature.org and http://www.icdlbooks.org and select two books and discuss in a group the Objective of Reading the books.

- Each group to create at least Five Questions on a given set of QRA pattern.

- Read in School or at Home and discuss in Library, Lunch or any other time physically or virtually by e-mailing or group posting on web.

- The team leader to gather data and the group creates a scrap book based on the reading and the questions.

- The team leader gathers data and together the group cooperates to create a presentation on the set of questions.

- There will be exchange of Scrapbooks and presentations for all to understand what others think, reflect and comprehend about the same text everyone has read. 


\section{Strengths of the program:}

- $\quad 100 \%$ participation.

- $\quad 100 \%$ communication.

- Collaboration with the language teacher who suggested the students to choose relevant texts which were related to the curriculum. For example students chose to read Shakespeare and created questions to find answers themselves.

- $\quad$ Grouping the students helped the ones who were not interested, to participate because of team spirit and presence of the team leader.

- With the scrap books and presentation in hand, it was possible for the teacher and librarian to know the levels of student learning out of the texts chosen.

- $\quad$ Dynamics of the team work and leadership were in practice.

\section{Weaknesses of the program:}

- $\quad$ Some of the students tried shifting the responsibility to the team leader and the team leader gave in.

Over all it was an excellent Reading Strategy to access Digitized Reading Resources and develop Reading communities in the school.

\section{TOOL-KIT of Free DIGLIBS for School Librarians}

1. List of free e-resources database with annotations organized alphabetically.

http://www.e-book.com.au/freebooks.htm

2. The Million Book Project.

Carnegie Mellon University School of Computer Science and University Libraries have joined hands with the Govt. and research partners in India and China. It is a free-toread access to the books on the web. More than million books have been made accessible from the following web site.

http://www.ulib.org

3. A site specifically designed for $\mathrm{K}-12$ students and educators. It offers teachers an easy-to-use guide to employing the Library of Congress online resources in the class room.

The content of the digital collections is presented in an appropriate context lessons, curriculum guides, "how to" projects and other learning activities. 
www.loc.gov/learn/

4. A collection of finest literature. The audio versions of the books are also available.

http://publicliterature.org/

5. The web site says,

"We have hundreds of classic books you can read right now, all absolutely free! It is an ideal way to expand your horizons, catch up on your reading list, or read books that it seems like everyone else has already read. Fix yourself a drink, get comfortable and Start Reading!"

http://www.pagebypagebooks.com/

6. 20,537 e books on varied collections, wonderful resource for research with formatting for PDA and iPods.

http://manybooks.net/

7. World Wide School library has enormous amount of resources apt for K12 schools on many subjects.

http://www.worldwideschool.org/library/catalogs/bysubject-top.html

8. The Baldwin Project focuses on literature for children published before 1923. It has wealth of online material suitable for children with a guide for parents and educators.

http://www.mainlesson.com/main/displayfeature.php

9. Text of all Jane Austen's novels.

http://www.pemberley.com/etext/

10. This Website provides links to "Thousands of Full-Text Free Books." The titles are grouped together by title within an alphabetical index. From there you can browse to find your favorite book

http://www.fullbooks.com/

11. The most comprehensive and well-researched anthology of all time comprises both the 50-volume "5-foot shelf of books" and the the 20 -volume Shelf of Fiction. Together they cover every major literary figure, philosopher, religion, folklore and historical subject through the twentieth century.

http://www.bartleby.com/hc

12. It is a project of the University of Maryland funded by the National Science Foundation and the Institute for Museum and Library Services. Launched in November 2002 features excellent children's world literature in very appealing and easy to navigate format. It is very good resource to create assignment for the whole school community. The Children's literature is in their original language and is searchable by 
simple and advanced location search by continent; by age group, type of books, by language and many more features.

http://www.icdlbooks.org

13. Founded by Michael Hart, the inventor of e books in 1971 is the oldest producer of free e books on the Internet. It is primarily a collection of literary works that are in public domain in the U.S. consists of light and heavy literature. You may also find books in additional languages in Chinese, Dutch, English, Finnish, French, German, and Spanish.

http://www.gutenberg.org

14. The Web site Provides unlimited access free of charge to students, researchers and anyone intellectually curious, to books and information. It features tremendous collection of Reference, Verse, Fiction and Non-Fiction for Librarians to develop reading communities at school.http://www.bartleby.com

15. There are 30'000 online English books in various formats free for personal and non-commercial use. In the listings, you can start reading a book by clicking on or selecting its title (or on the phrase that describes where it is, if you're looking at a detailed book description, or at a listing that has multiple links).

You can also select the $\mathbf{i}$ icon at the start of a book listing to find out more about a particular book, find other books with the same author, title, or subject, or find out how to make a stable link to the detailed book description http://digital.library.upenn.edu/books/

16. Full text of 2100 e books consisting of Illustrated Classics,AfricanAmerican, Native American, Women writers, Young readers, which may be browsed by Subject and Author.http://etext.lib.virginia.edu/ebooks/

17. Online illustrated stories for young Readers.

http://www.beenleigss.qld.edu.au/requested sites/storiesontheweb/storiesonthewe $\underline{\text { b.html }}$

18. 10 amusing and illustrated stories for young readers. http://www.ipl.org/div/kidspace/storyhour/

19. Pre-school thematic library of Audio books with fun activities. http://www.storyplace.org/preschool/other.asp

20. Elementary thematic library with fun filled activites.

http://www.storyplace.org/eel/other.asp

21. Audio stories.

http://www.bbc.co.uk/cbeebies/tweenies/storytime/stories/index.shtml 
22. A collection of full 700 e-texts mostly of Literature, Philosophy, Science and Medicine.http://etext.library.adelaide.edu.au/meta/titles.html

23. A treasure trove of literature. http://gutenberg.net.au/

24. Free online Literature consisting of 2000 classic texts. It holds Literature Book Notes, Author Biographies, Book Summaries and Reference Books. One can also read Classic Fiction, Drama, Poetry, Short Stories and contemporary articles and interviews. Find study guides to the most read books and help for teachers. http://www.bibliomania.com.

25. A union catalog of Electronic books, Texts and documents. It provides links to more than 1,41000 full text digital books from 1800 commercial and non commercial publishers, universities and private sites. More than 100,000 of the e texts are free. http://www.digitalbookindex.org/about.htm

26. Digitized History resources converted from project Gutenberg http://www.nalanda.nitc.ac.in/resources/english/etext-project/history/history.htm

27. Wired for books web site offers a collection of Beatrix Potter's stories for children in real/audios in English, French, German and Japanese. The website is a literary festival to listen to the readings and lectures of noted authors.

http://www.wiredforbooks.org/index2.htm

28. National Science Digital Library targets to provide more Science and Mathematics enrichment into out-of school time using resources from the Exploratorium Digital Library.

http://www.exploratorium.edu/educate/dl.html

29. Full text books and journal articles on Science and related fields.

http://www.sciencedirect.com

30. Spanish Language and literature Resources

http://www.cervantesvirtual.com/index.jsp

31. Internet Public Library is an excellent tool to promote reading and researching for school students. A

Collection of literature is ideal for experimenting with students to read online through digital libraries. http://www.ipl.org

\section{CONCLUSION}

It started with Brian Hawkins and let it conclude with what Hawkins has said about the future libraries which has become a present. 
"The library of the future will be less a place where information is kept than a portal through which students and faculty will access the vast information resources of the world."

What a vision it was!

But the challenge for us as schools librarians is to continue laying the foundations for this new environment, and still keep dreaming and striving for higher and yet higher visions.

\section{REFRENCES}

Wallis, Claudia and Steptoe, Sonja (2006). How to bring our schools out of $20^{\text {th }}$ Century. Retrieved Jan. $16^{\text {th }}, 2008$ from http://trailfire.com/pages / form.php?aid=check\&bubble=97604

Culligan, M (2003). Digital natives in the classroom. In B. Hoffman (Ed.), Encyclopedia of Educational technology. Retrieved April 23, 2008 from http://coe.sdsu.edu/eet/articles/digitalnatives/start.htm

Record, Sara (1996), A Library for the Ages, Learning page, multiversity, pg.4

Dexter, Martha (1996), back to school with learning page; news from the National

Digital Library. Retrieved Jan $29^{\text {th }}, 2008$ from http://www.loc/Icib/9614/ndl.html

Lamolinara, Guy (2004). The National Digital Library at 10 from the Library of Congress information Bulletin. Retrieved Jan.29,2008 from http://www.loc.gov/loc/Icib/ndl.html

Read Write Think: Lesson plan: using QARs to develop comprehension from http://www.readwritethink.org/lessons/lesson view.asp?Id-23, and 67

Audrey, P.Church (2005), Multimedia and Internet @ schools magazine: E Book Resources for school library from http://www.mmischools.com/Articles/ArticleID=10110

Eshet-Alkali Y and Amichal-Hamburger Y (2004), Experiments in digital literacy[cyberpsychol Behav.Pub.Med.] accessed on January 16,2008 from http://www.ncbi.nlm.nih.gov/sites/entrez?db=pubmed\&uid=15331029\&cmd=showdetailvi

Prensky, Marc (2001), Digital natives, Digital immigrants from on the Horizon CNCB University Press, vol. 9 No. 5, October 2001.

Bloom,Nena E and Stout, Cynthia (2005), Using digitized primary source materials in the classroom: A Colorado case study, First Monday,Volume 10, number 6 (June 2005) accessed from http://firstmonday.org/issues/issue10 6/bloom/index.html on 13.05.2008.

Welcome to the school Library campaign @ your library from http://www.ala.org/als/pio/campaign/schoollibrary/schoollibrary.cfm accessed 24.04.2008. 
Buehl, D. (2001). Question-Answer Relationships. In Classroom Strategies for Interactive learning $\left(2^{\text {nd }}\right.$ ed.). Newark, DE: International Reading Association accessed from

http://www.readwritethink.org/lessons/lesson view.asp?id=23 on 09.05.2008

Eisenberg, Michael B. and Berkowitz, Robert E. (1987), "the Big 6" accessed from http://www.big6.com on April 24, 2008.

\section{BIBLIOGRAPHY}

Guthrie, Jont et al. Concept-oriented reading instruction: and integrated curriculum to develop motivations and strategies for reading, http://www.teach.virginia.edu/gov/clil/nrrc/cori r10.html

David Seaman (1997), The user community responsibility and resource: building as sustainable digital library, D-Lib magazine, July/August 1997. http://www.dlib.org/dlib/july/07seaman.html

Glister, Paul (1997), Digital Literacy, John Wiley and sons.

Lakshamana Moorthy, A. and Karisiddappa, C.R.(1998). Transformation to virtual Libraries: real or virtual? [In society for Information science, Annual conference (University of Hyderabad).

Fox, E. and Lunin, L (1993), perspectives on Digital Libraries: introduction and overview. Francisco, CA.

Lesk, M. (1997), Practical Digital Libraries: Books, Bytes and Bucks, Morgan Kaufman, San

Markuson, Carolyn (1999), Preface to information literacy in Action by Carol Gordon, John Catt., U.K.

Digital Library Federation (1998), A working definition of a digital library accessed from http://www.diglib.org/about/dldefinition.htm on 13.05.2008. 


\title{
Biographical Notes
}

\author{
Bhargava, Madhu
}

Dean of Libraries at G.D.Goenka World School, India has twenty years of working experience in various school libraries in India. She is a Graduate in Arts and a Post Graduate in Library and Information Sciences from India. She represents India to International Baccalaureate Asia Pacific and works passionately to implement Information Literacy across the curriculum. She has contributed 'Capacity Building Training Modules for School Librarians of India' (Information Literacy and E-Resources) to the National Educational Research and Training Institute of India. She has been awarded by Indian Library Association for developing 'Best School Library' in 2003. International Association of School Librarianship, Australia also awarded her Ken Haycock Leadership Development grant in 2005 at Hong Kong.

\section{Statement of Originality}

This statement certifies that the paper above is based upon original research undertaken by the author and that the paper was conceived and written by the author alone and has not been published elsewhere. All information and ideas from others is referenced. 